\title{
ANALYSIS AND TESTING OF RELIABILITY INFORMATION SYSTEMS IN ANALYSIS OF THE OPERATION-RELATED PROCESS IN THE ARMY
}

\section{SYSTEMY INFORMATYCZNE W ANALIZIE PROCESU EKSPLOATACJI W WOJSKU}

\author{
Przemysław Simiński ${ }^{1}$, Jarosław Kończak ${ }^{1}$, Kamil Przybysz ${ }^{2}$ \\ ${ }^{1}$ Military Institute of Armoured and Automotive Technology, \\ Wojskowy Instytut Techniki Pancernej i Samochodowej \\ ${ }^{2}$ Polish Air Force University. Lotnicza Akademia Wojskowa
}

\begin{abstract}
This paper focuses on the determination of effectiveness of the implemented system ZWSI RON in an analysis of the vehicles operation process in the army. With this end in view, a questionnaire-based diagnostic survey was conducted on staff members of the technical services of the Polish Army logistics units. The survey research results analysis shows that $90 \%$ of the respondents do not use the basic PM (Plant Maintenance) module of the ZWSI RON system to manage the operation of military vehicles. One should consider a modification of the mentioned system, i.e. creating new modules and new relations between individual modules of the system, using SAP system structure solutions.
\end{abstract}

Keywords: information system, operation support, system effectiveness

Streszczenie: Tematem publikacji jest określenie efektywności wdrożonego systemu informatycznego ZWSI RON w analizie procesu eksploatacji pojazdów w wojsku. $W$ tym celu przeprowadzono badania metoda sondażu diagnostycznego, z zastosowaniem techniki badań ankietowych, przy wykorzystaniu osób funkcyjnych zatrudnionych w stużbach technicznych struktur logistycznych Wojska Polskiego. Analiza uzyskanych wyników badań ankietowych dowodzi, że 90\% respondentów nie wykorzystuje podstawowego modutu PM (ang. Plant Maintenance) systemu ZWSI RON do zarządzania eksploatacja pojazdów wojskowych. Powinna zostać rozważona modyfikacja wspomnianego systemu, polegajaca na stworzeniu nowych modutów oraz nowych relacji pomiędzy jego poszczególnymi modułami, wykorzystując rozwiazania architektury systemu SAP.

Slowa kluczowe: system informatyczny, wspomaganie eksploatacji, efektywność systemu 
Analysis and testing of reliability information systems in analysis of the... Systemy informatyczne $w$ analizie procesu eksploatacji w wojsku

\section{ANALYSIS AND TESTING OF RELIABILITY INFORMATION SYSTEMS IN ANALYSIS OF THE OPERATION-RELATED PROCESS IN THE ARMY}

\section{Introduction}

A continuous need exists to introduce changes whereby the military logistics system of the Armed Forces of the Republic of Poland (SZ RP) would be adapted to operation within the NATO logistics environment in order to carry out projects related to achieving technical and technological interoperability. Such changes also drive the development of IT tools designed to support logistics management processes. [6]

At present, the army is implementing a program aimed at the integration, within a single system, of all data on the operation of technical objects. Military logistics took a new direction when, in 2012, the new IT system, i.e. the Integrated MultiLevel IT System of the Polish Armed Forces (ZWSI RON), was put into operation in line with a decision taken by the Minister of National Defence. The implementation of this system in the SZ RP forced mass migration of data regarding operation of military equipment ( $\mathrm{SpW}$ ) from IT systems previously used to provide support for $\mathrm{SpW}$ operation processes in the Polish Armed Forces (WP).

However, even though it has been five years since the implementation of ZWSI RON, the system still fails to meet expectations, according to opinions of its direct users and persons who indirectly use it for managing SpW. Personnel involved in military logistics activities claims that the system in question is not a comprehensive supporting tool as far as the operation of $\mathrm{SpW}$ is concerned. This thesis finds confirmation in the results of the survey conducted on staff members of the technical services of the Polish Army logistics structures who are directly involved in the operation of military vehicles.

In order to explain the origin of the current problems with the operation of ZWSI RON, one should analyse decommissioned systems, from which data was transferred to the currently used IT system. Additionally, a modification of the mentioned ZWSI RON system should be considered with remarks from its users taken into account.

Considering modification opportunities offered by the implemented ZWSI RON system, which is based on the SAP architecture (in German: Systemanalyse und Programmentwicklung - provider of ERP-class business software for businesses from all branches and sectors of economy), it is worth it to take into account solutions that have been already put into operation in the civilian sector. 


\section{Analysis of IT system used by the Polish Armed Forces}

According to what has been said before, when analysing problems related to operation of ZWSI RON IT system, as currently implemented in the SZ RP, in the first place it is necessary to take into account previous, separate systems that were used in functional sections of military units, i.e. in logistics, chief accountant and HR sections. Data archived in individual IT systems were not interrelated at all because there was no integration whatsoever between IT systems used in the above-mentioned functional sections. It was not possible to exchange data not only between the mentioned systems but also between different levels of command within a specific system. Unfortunately, all this not interrelated data migrated to the data base of ZWSI RON.

For a long time, operation of $\mathrm{SpW}$ in military units has been supported using two independent systems of LOGIS-E-OG and SIGMAT-RBM classes. Both systems were equipped with poorly developed applications, which allowed only keeping military records and generating reports on the turnover of material means entered in the above-mentioned systems. Property inventories kept by individual services of the logistics section were compared with the quantity and value records of the chief accountant section using print-outs from respective systems. Records from the LOGIS-E-OG system kept at the military unit were compared with records kept at a higher level of command in a similar way. Data was updated on quarterly basis based on analysis of operation records kept by the subordinate and the superior.

As a result of the above-mentioned practices, there was no consistent knowledge of turnover of materials both within a military unit (between the chief accountant section and e.g. the tank and automotive service), and on individual levels of command. The lack of integration between IT systems resulted in lower efficiency of repair units and consequently reduced the ability of military units to achieve readiness for action.

As the first step towards the unification of IT systems employed in SZ RP, in 2006 a new indexation system was put into operation: The Unified Material Index (JIM), which improved and unified the coding system covering all items of supply on the national level. Additionally, the introduction of JIM made it possible to identify defence products in order to mark them using NSNs (NATO stock number), which significantly influenced the interoperability of the armed forces in international operations.

The introduction of the system of unified codes for defence products (JIM) in 2012, made it possible to implement ZWSI RON system, which replaced previous, completely incompatible IT systems with a single, centralized, integrated, unified, multi-module system capable of serving individual functional sections of a military unit and thus allowing logistics to function in a network-centric environment.

The basic advantage of the SAP architecture-based ZWSI RON system is in the first place its multi-module structure. 
Analysis and testing of reliability information systems in analysis of the... Systemy informatyczne $w$ analizie procesu eksploatacji w wojsku

The system, as used by SZ RP, consists of SAP/R3 modules (where R means the real-time operation while " 3 " means the level of the system architecture):

- MMSD - Materials Management-Sales and Distribution,

- FI-FM - Financial Accounting Funds Management,

- FI-AA - Asset Accounting,

- PM - Plant Maintenance.

Unfortunately, the core of the above-mentioned system is made of inconsistent data, which migrated from the previously used systems. Data transferred to the PM module are of a purely recording nature and are of little use when it comes to supporting operation of technical objects. As an advantage of placing these data in the new system comes their interrelation owing to the multi-modular structure of the system. Another asset is the fact that the complete data flow and updating as well as all operations are performed in the system in real time, which helps the user take decision on a current basis.

However, the above system still lacks a module that would make it possible to assess, on a current basis, operational properties (readiness, reliability) of complex technical objects such as military vehicles.

Abilities of SAP solutions, which are much higher than those used in ZWSI RON, have been presented in papers $[4,5]$, which show the optional possibility of using operational events as triggers for interconnected processes within a process used to handle information about a failure of equipment. Using combined information from different modules, the system can generate comprehensive information related to the determination of possible ways of correcting faults of technical objects and thereby show weak links of the system that make it impossible to reach success. The determined probability of successful completion of handling reported failure will depend on the quality of models used to present the mentioned processes on the IT system level. The above SAP architecture-based system is capable of controlling the complete life-cycle of a technical object [7].

\section{Studies on the effectiveness of IT systems}

Effectiveness of the implemented ZWSI RON IT system in the analysis of operation of military vehicles was assessed using a questionnaire-based diagnostic survey, which was conducted on staff members of technical services of logistics units of the Polish Armed Forces. The survey was carried out on a representative group of 120 staff members who directly or indirectly used the system in question in the process of supporting operation of military motor vehicles. This number of respondents accounts for $24 \%$ of the total population found in the tank and automotive service section of the Polish Armed Forces, which manages the operation of military vehicles. The respondents included:

- Section managers on the WOG (military economic unit) level,

- Section managers on the RBLog (regional logistics base) level,

- employees responsible for the operation of SpW,

- Employees responsible for the supplies of spare parts. 
The surveyed persons marked personally, in an anonymous questionnaire, correct answers in line with their individual knowledge and experience. The survey contained the following questions:

- Mark operation-related documents you work with:
a. travel order,
b. job card,
c. KUT (technical service card),
d. Operation plan
e. Battery, tire and canvas cover rotation plan,
f. Activity-and-finance plan,
g. Diagnostic test plan;

- Specify the form of reporting documents and balance sheets (e.g. for chiefs/commanders):
a. paper,
b. MS Excel spreadsheet,
c. MS Word tables,
d. ZWSI RON,
e. MS Access,
f. other (specify):

- Do you know the following designations?
a. IM/WP-68,
b. JIM,
c. $\mathrm{KH}$,
d. IS (as administrator),
e. ZWSI RON,
f. PM module,

- Does your military unit use the ZWSI RON system?
a. yes,
b. no;

- Do you use the PM module to manage operation of equipment?
a. yes,
b. no;

- In your opinion, how user-friendly is the ZWSI RON system?
a. user-friendly,
b. complicated,
c. friendly,
d. difficult;

- Explain meanings of the following terms in the ZWSI RON system:
a. depot,
b. establishment,
c. consignment;

- What problems occur in your military unit in the process of recording operational events related to vehicles ( $\mathrm{SpW}$ ) (space was left for respondents to provide their answers)? 
Analysis and testing of reliability information systems in analysis of the... Systemy informatyczne $w$ analizie procesu eksploatacji w wojsku

In the analysis of the first question, one can assume that surveyed persons know and work with standard operation-related documents, as shown in figure 1.

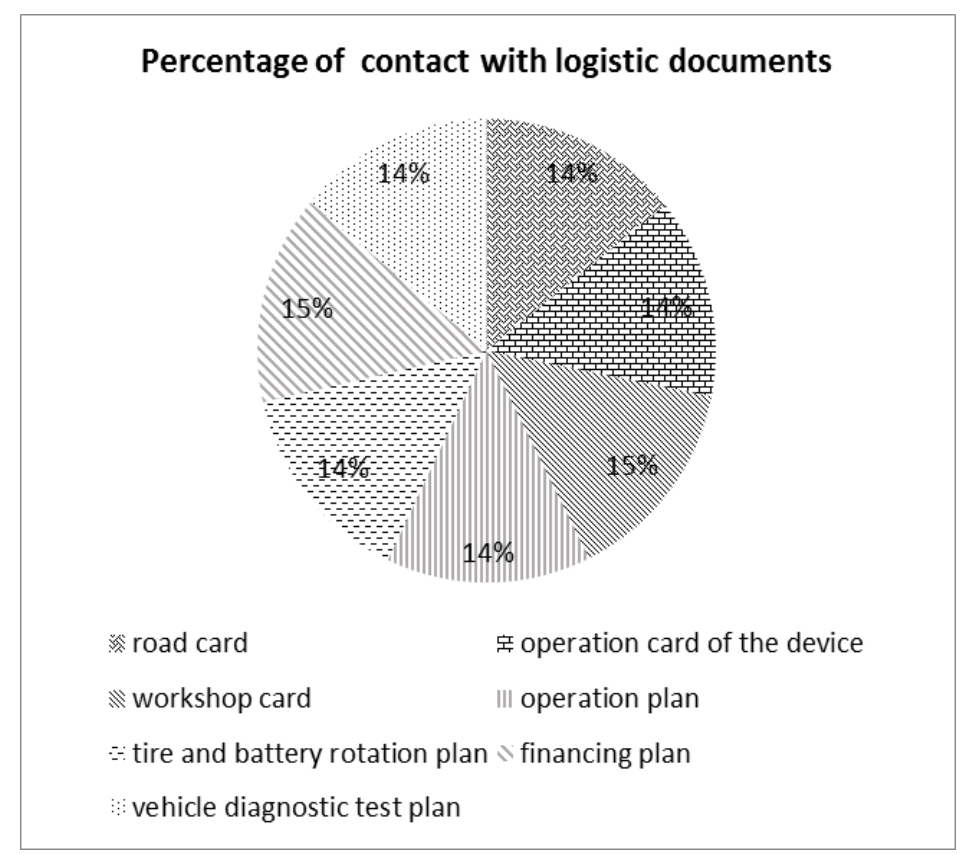

Fig. 1 Percentage distribution of contact with logistics documents

According to answers to the second question, all the respondents still draw up reporting documents related to the operation of $\mathrm{SpW}$ using the MS Excel spreadsheet, as clearly shown in Figure 2.

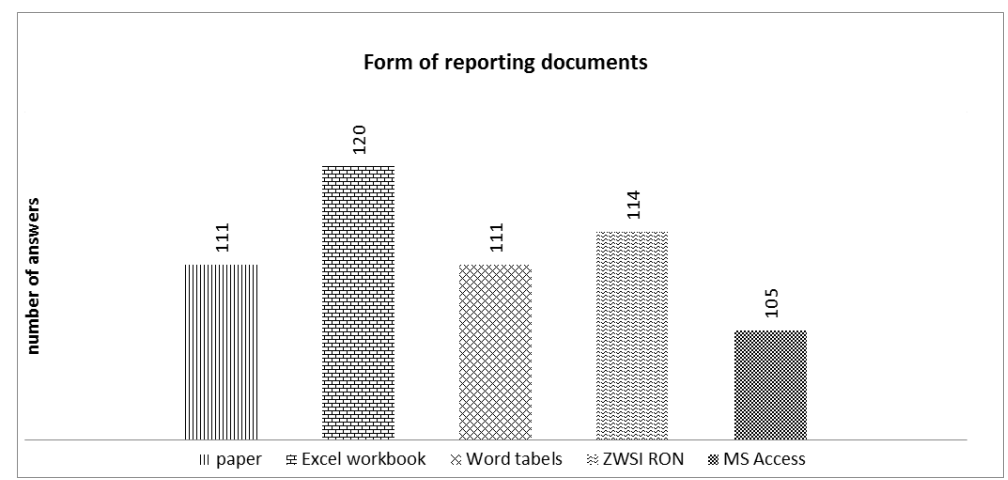

Fig. 2 Form of reporting documents

However, one should note the fact that also ZWSI RON is used to a large extent to draw up the documents in question (95\% of the respondents). 
As far as the above-mentioned area is concerned, the least used tool is the MS Access suite, which is an alternative to MS Excel but it needs more IT skills from the user.

Answers to the third question regarding knowledge of the basic terms related to the operation of ZWSI RON show that most respondents know basic terms used in this area very well or well, e.g. the terms JIM and ZWSI RON were explained by $100 \%$ and $96 \%$ of the respondents, respectively. However, the term "PM module", as a component part of ZWSI RON, was known to about $50 \%$ of the surveyed, which suggests that not all of them know the structure of ZWSI. It was more difficult for the respondents to answer question 7 pertaining to more advanced terms related to ZWSI RON, which denotes average (below 50\%) user's knowledge of the system.

Then, questions 4 and 5, as shown above, and answers to them show that $75 \%$ of the respondents use ZWSI RON for their business purposes but only $10 \%$ of the surveyed declared that they used the PM module to manage operation of equipment.

Answers to question 6 about user-friendliness of the system have been provided by the marking of the presented indicators, as shown in Figure 3.

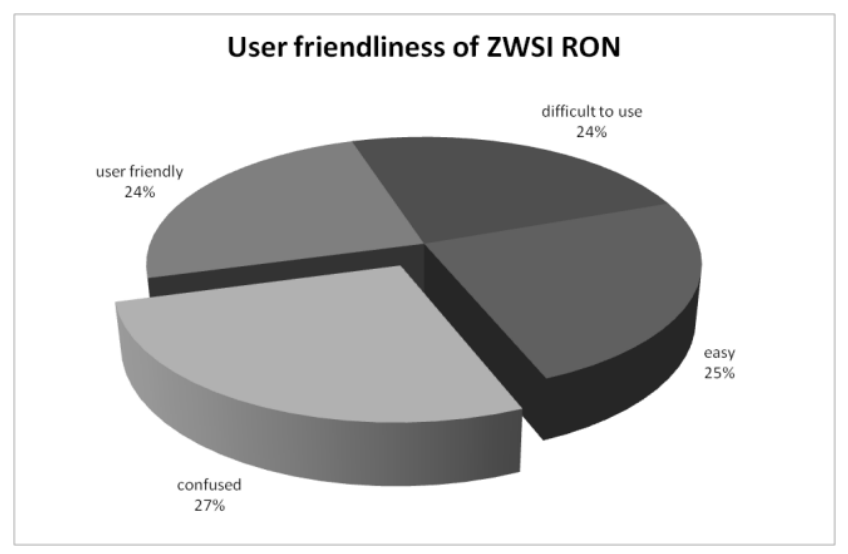

Fig. 3 System assessment providing user friendliness

When analysing the assessment of the ZWSI RON system with user-friendliness taken into account, one can see a balanced distribution of individual indicators: friendly, difficult, user-friendly, complicated. Based on the subjective opinions provided by the respondents, it is not possible to clearly decide if the system is easy or difficult to use. However, the highest percentage share (27\%) falls to answers suggesting that the system is complicated or not user-friendly.

Most information about the use of the ZWSI RON system for supporting operation of military vehicles came from answers to question 8 where respondents had an opportunity to express freely in writing their opinions about and assessment of the system. 
Analysis and testing of reliability information systems in analysis of the... Systemy informatyczne $w$ analizie procesu eksploatacji w wojsku

The research material collected here is fairly extensive and thus in the following the most frequent answers are shown, in which problems related to recording operational events are mentioned:

- "ZWSI includes only quantity and value records, the PM module not implemented";

- "ZWSI lacks the option of executing an operation plan";

- "ZWSI doubles documents or generates unnecessary ones";

- "ZWSI is ineffective and crashes";

- "In ZWSI, it is not possible to generate reports regarding accepting/handingover a vehicle from/to other services while these are required by the regulations";

- "ZWSI lacks the entries that are present in the motor vehicle books";

- "staff shortages - too few personnel to keep the complete records of operation";

- "the system slows down the document flow";

- "no synchronization between the military economic unit (WOG) and users and within the WOG-WOG relations";

- "delayed provision of data necessary to plan operation; unreliable data";

- "ZWSI RON offers no possibility of mapping operational events that the tank and automotive service records for other logistics services of the military unit".

The above recurring answers to question 8 provide subjective, independent opinions and conclusions regarding the operation of ZWSI RON. In their answers to this question, the participants of the survey could present their observations and show problems they face in their day-to-day use of the above IT system. According to their opinions, ZWSI RON system assumptions do not match the actions they are obliged to perform under industry instructions $[1,2]$.

\section{Summary}

The research results collected show in the first place that even though the ZWSI RON system has been put into operation, reporting documents, balance sheets, etc. in military units are still made using alternative methods. This is clearly shown by the data presented in Figure 2. Unfortunately, in this area, staff members responsible for logistics in military units continue to informally implement commercial solutions such as the MS Excel spreadsheet and MS Access in order to support operation-related processes and such solutions are used on par with ZWSI RON [3]. Persons involved in providing IT support for processes related to the operation of civilian vehicles may wonder why military units use additional (besides ZWSI RON system) IT tools even though more specialized tools for recording operational events are easily available. Contrary to suppositions, this does not result from insufficient knowledge of IT or civilian market on the part of military staff members responsible for logistics. One should realize that computers used in military units and connected to the military classified network MILNET-Z are subject to restrictions imposed by regulations regarding protection of classified information.

As one of such restrictions, it is forbidden to install software that has not been cleared for using in classified networks by the Military Counterintelligence Service. The above-mentioned IT tools, i.e. MS Excel or MS Access, are part of the MS Office suite, which is installed and available on computers connected to the MILNET-Z network. 


\section{References}

[1] IWsp SZ Służby Techniczne, Instrukcja Zarządzania Eksploatacją Uzbrojenia i Sprzetu Wojskowego w SZ RP Zasady Ogólne, DD/4.22.13, Bydgoszcz, IWsp SZ, 2013.

[2] IWsp SZ Służby Techniczne, Przepisy o gospodarowaniu sprzętem służby czołgowo-samochodowej, DD/4.22.2, Bydgoszcz, IWsp SZ, 2014.

[3] Kończak J. Polak K., Radzikowska B., Ewidencjonowanie zdarzeń eksploatacyjnych sprzętu czołgowo-samochodowego w czasie pokoju, spojrzenie w przyszłość, Sulejówek, Belstudio, 2013.

[4] Kuck J., Nowoczesne technologie w logistyce, Wydawnictwo AON, Warszawa 2013.

[5] Markowska K.: Proponowany przebieg współpracy outsourcingowej na przykładzie usług transportu kolejowego ładunków, Organizacja i Zarządzanie, Zeszyty Naukowe Nr 1928, Politechnika Sląska, Gliwice 2015r. s. $249-262$.

[6] Samól D., Kuck J., Współczesne metody wsparcia informatycznego dla logistyki kadr i finansów, [w:] Perspektywy informatyzacji logistyki Wojska Polskiego, SG WP, Logis. Wewn. 4/2006

[7] Simiński P., Wojskowe Pojazdy Kołowe, Bel Studio, Warszawa, 2015

[8] Żółtowski B., Badania zagrożeń utraty zdatności środowiskowych systemów technicznych, Bydgoszcz, Wyd. Ucz. UT-P, 2013.

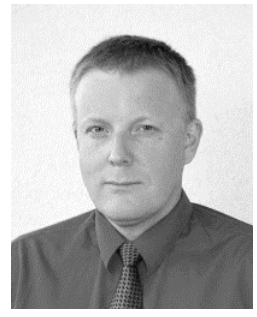

Col. Przemyslaw Simiński Ph.D. Eng., associate professor, graduate of the faculty of Mechanical Engineering of the Military University of Technology. Deputy Manager of WITPiS. Project Manager. Lecturer, academic teacher (Share 40\%).

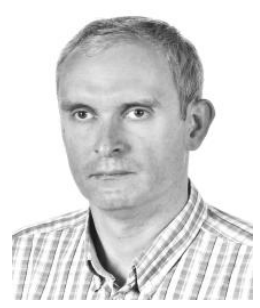

Jaroslaw Kończak Ph.D. Eng., graduate of the faculty of Mechanical Engineering of the Military University of Technology. Reader at WITPiS, logistics and equipment operation expert, designer, ergonomic engineer. Project Manager (Share 30\%).

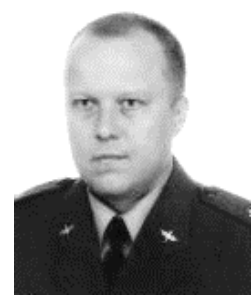

Mjr Kamil Przybysz Ph.D. Eng., graduate of the faculty of Mechanical Engineering of the Military University of Technology reader at Aeronautics Faculty of Polish Air Force Academy, logistics and equipment operation expert, programmer, analyst, IT systems manager (Share 30\%). 
Analysis and testing of reliability information systems in analysis of the... Systemy informatyczne $w$ analizie procesu eksploatacji w wojsku

\section{SYSTEMY INFORMATYCZNE W ANALIZIE PROCESU EKSPLOATACJI W WOJSKU}

\section{Wstęp}

Istnieje ciągła potrzeba zmian, dotyczących dostosowania systemu logistyki wojskowej Sił Zbrojnych RP do funkcjonowania w środowisku systemu logistycznego NATO, w celu realizacji przedsięwzięć związanych z osiąganiem interoperatywności technicznej i technologicznej. Powyższe zmiany wymuszają także rozwój narzędzi informatycznych wspomagających procesy kierowania logistyką. [6]

Obecnie w wojsku realizowany jest program, mający na celu zintegrowanie wszystkich danych, dotyczących eksploatacji obiektów technicznych, w jednym systemie informatycznym. Wprowadzenie decyzją Ministra Obrony Narodowej do eksploatacji w 2012 r. nowego systemu informatycznego - Zintegrowanego Wieloszczeblowego Systemu informatycznego Resortu Obrony Narodowej (ZWSI RON), zapoczątkowało nowy kierunek informatyzacji logistyki w wojsku. Implementacja przedmiotowego systemu w SZ RP wymusiła masową migrację danych eksploatacyjnych sprzętu wojskowego (SpW) $\mathrm{z}$ poprzednio wykorzystywanych systemów informatycznych, wspierających procesy eksploatacji SpW w Wojsku Polskim (WP).

Pomimo jednak upływu pięciu lat od momentu wdrożenia ZWSI RON, nadal powyższy system informatyczny, w opiniach jego bezpośrednich użytkowników oraz osób wykorzystujących pośrednio ten system do zarządzania eksploatacją $\mathrm{SpW}$, nie spełnia ich oczekiwań. Według członków personelu logistyki wojskowej przedmiotowy system nie stanowi kompleksowego narzędzia wspomagającego proces eksploatacji SpW. Potwierdzeniem przedmiotowej tezy są wyniki badań ankietowych, przeprowadzone przy wykorzystaniu osób funkcyjnych zatrudnionych w służbach technicznych struktur logistycznych WP, biorących czynny udział w procesie eksploatacji pojazdów wojskowych.

W celu wyjaśnienia genezy bieżących problemów, związanych z funkcjonowaniem ZWSI RON, należy dokonać analizy systemów wycofanych $\mathrm{z}$ eksploatacji, z których dane migrowały do obecnie funkcjonującego systemu informatycznego. Ponadto należy rozważyć modyfikację wspomnianego systemu ZWSI RON, odnosząc się do uwag, sformułowanych przez jego użytkowników.

Biorąc pod uwagę możliwości modyfikacji, jakie daje nam wdrożony system ZWSI RON, oparty na architekturze SAP (niem. Systemanalyse und Programmentwicklung - dostawca oprogramowania biznesowego klasy ERP dla przedsiębiorstw ze wszystkich branż i sektorów gospodarki), warto jest rozważyć rozwiązania już zaimplementowane w przedsiębiorstwach cywilnych. 


\section{Analiza systemów informatycznych w Wojsku Polskim}

Analizując problemy związane $\mathrm{z}$ funkcjonowaniem obecnie zaimplementowanego do SZ RP systemu informatycznego ZWSI RON, jak wspomniano we wstępie, należy przede wszystkim odnieść się do uprzednio funkcjonujących, odrębnych systemów w poszczególnych pionach funkcjonalnych jednostek wojskowych: w pionie logistyki, pionie głównego księgowego oraz w pionie kadr. Dane archiwizowane w poszczególnych systemach informatycznych nie były w ogóle ze sobą powiązane, ponieważ nie zapewniono integracji pomiędzy systemami informatycznymi funkcjonującymi w wymienionych pionach funkcjonalnych. Niemożliwy był przepływ danych zarówno pomiędzy wspomnianymi systemami, jak i również $\mathrm{w}$ obrębie konkretnego systemu, ale na różnych poziomach dowodzenia. Niestety wszystkie te nie powiązane ze sobą dane migrowały do bazy danych systemu ZWSI RON.

Eksploatacja $\mathrm{SpW}$ w jednostkach wojskowych była przez długie lata wspierana głównie przez dwa niezależne systemy klasy LOGIS-E-OG oraz SIGMAT-RBM. Powyższe systemy posiadały słabo rozwinięte oprogramowanie użytkowe, umożliwiające jedynie prowadzenie ewidencji wojskowej oraz wykonywanie sprawozdań, dotyczących obrotów środków materiałowych, zaksięgowanych na ewidencji powyższych systemów. Ewidencja majątku w poszczególnych służbach pionu logistyki była porównywana $\mathrm{z}$ ewidencją ilościowo-wartościową pionu głównego księgowego przy wykorzystaniu wydruków, wygenerowanych z przedmiotowych systemów. Podobnie odbywało się porównywanie ewidencji z systemu LOGIS-E-OG prowadzonej na szczeblu JW z ewidencją prowadzoną na wyższym szczeblu dowodzenia. Aktualizacja danych odbywała się w cyklu kwartalnym poprzez analizę dokumentacji eksploatacyjnej podwładnego i przełożonego.

Powyższe zjawiska powodowały brak spójności odnośnie posiadanej wiedzy w zakresie obrotów materiałowych, zarówno w obrębie jednostki wojskowej (pomiędzy pionem głównego księgowego oraz np. służby czołgowosamochodowej), jak i na poszczególnych szczeblach dowodzenia. Brak integracji pomiędzy systemami informatycznymi powodował obniżenie sprawności działania pododdziałów remontowych, a tym samym obniżał zdolności do osiągania gotowości do podjęcia działań przez jednostki wojskowe.

Pierwszym krokiem w celu ujednolicenia systemów informatycznych funkcjonujących w SZ RP, było wprowadzenie w 2006 r. do użytku nowego systemu indeksacji: Jednolity Indeks Materiałowy (JIM), który usprawnił i ujednolicił system kodyfikacji wszystkich środków zaopatrzenia w układzie narodowym. Ponadto wprowadzenie JIM stworzyło warunki do identyfikacji wyrobów obronnych w celu nadania im Natowskiego Numeru Magazynowego (NSN-NATO stock numer), co istotnie wpłynęło na interoperatywność wojsk w działaniach międzynarodowych. 
Analysis and testing of reliability information systems in analysis of the... Systemy informatyczne $w$ analizie procesu eksploatacji w wojsku

Wprowadzenie jednolitego systemu kodyfikacji wyrobów obronnych JIM umożliwiło w 2012 r. implementację ZWSI RON, który zastąpił dotychczas funkcjonujące, zupełnie niekompatybilne ze sobą systemy informatyczne, w jeden scentralizowany, zintegrowany, zunifikowany, wielomodułowy system obsługujący poszczególne piony funkcjonalne JW, umożliwiając tym samym funkcjonowanie logistyki w środowisku sieciocentrycznym.

Podstawową zaletę systemu ZWSI RON, opartego na architekturze systemu SAP stanowi przede wszystkim jego wielomodułowość. Przedmiotowy system użytkowany w SZ RP tworzą moduły systemu SAP/R3 (R oznacza działanie w czasie rzeczywistym (ang. realtime), natomiast cyfra 3 oznacza poziom architektury systemu):

- MMSD, gospodarka materiałowa, sprzedaż i dystrybucja (ang. Materials Management-Sales and Distribution),

- FI-FM, rachunkowość finansowa (ang. Financial Accounting Funds Management),

- FI-AA, majątek trwały (ang. Asset Accounting),

- PM, eksploatacja (ang. Plant Maitenance).

Niestety rdzeń bazy danych powyższego systemu stanowią niespójne dane, które migrowały $\mathrm{z}$ uprzednio funkcjonujących, wspomnianych powyżej systemów. Przeniesione dane do modułu PM - eksploatacja mają charakter czysto ewidencyjny i niewiele wnoszą do wsparcia procesu eksploatacji obiektów technicznych. Zaletą osadzenia tych danych w nowym systemie jest ich wzajemne powiązanie, co umożliwia wielomodułowość przedmiotowego systemu. Dodatkowym atrybutem jest fakt, że cały przepływ danych oraz ich aktualizacja i wszystkie operacje wykonywane są w systemie w czasie rzeczywistym, co ułatwia użytkownikowi podejmowanie bieżących decyzji.

Nadal jednak w powyższym systemie nie ma modułu, który umożliwiałby bieżącą ocenę podstawowych właściwości eksploatacyjnych (gotowość, niezawodność) złożonych obiektów technicznych, jakimi są np. pojazdy wojskowe.

Znacznie większe możliwości rozwiązań SAP, niż te wykorzystywane w ZWSI RON zobrazowano $w$ pracach $[4,5]$, gdzie zobrazowano możliwości ujęcia zdarzeń eksploatacyjnych, jako elementów inicjujących powiązane ze sobą procesy, w ramach procesu przetwarzania zgłoszeń o uszkodzeniu sprzętu. Łącząc informacje z poszczególnych modułów system może wygenerować kompleksową informację dotyczącą określenia możliwości usuwania usterek obiektów technicznych, wskazując słabe ogniwa systemu, uniemożliwiające osiągnięcie sukcesu. Określenie prawdopodobieństwa zakończenia realizacji zgłoszenia uszkodzenia sukcesem będzie uwarunkowane jakością modeli wspomnianych procesów, na poziomie systemu informatycznego. Powyższy system, oparty na architekturze SAP ma możliwości kontroli całego cyklu życia obiektu technicznego [7]. 


\section{Badania efektywności systemów informatycznych}

Efektywność wdrożonego systemu informatycznego ZWSI RON w analizie procesu eksploatacji pojazdów w wojsku, oszacowano na podstawie badań przeprowadzonych metodą sondażu diagnostycznego, z zastosowaniem techniki badań ankietowych, przy wykorzystaniu osób funkcyjnych zatrudnionych w służbach technicznych struktur logistycznych Wojska Polskiego. Przedmiotowe badania przeprowadzono na reprezentatywnej grupie 120 osób funkcyjnych, bezpośrednio lub pośrednio wykorzystujących przedmiotowy system w procesie zabezpieczenia eksploatacji wojskowych pojazdów mechanicznych. Powyższa liczba respondentów stanowi $24 \%$ całej populacji pionu służby czołgowosamochodowej SZ RP, zarządzającą eksploatacją pojazdów wojskowych. Wśród ankietowanych byli:

- kierujący sekcjami na szczeblu WOG-ów,

- kierujący Sekcjami na szczeblu RBLog-ów,

- pracownicy odpowiedzialni za eksploatację SpW,

- pracownicy odpowiedzialni za zaopatrywanie w części zamienne.

Ankietowane osoby zaznaczały właściwe odpowiedzi według indywidualnej wiedzy oraz posiadanego doświadczenia, wypełniając osobiście, anonimową ankietę. Powyższa ankieta zawierała następujące pytania:

- Proszę podać z jakimi dokumentami eksploatacyjnymi Pani/Pan pracuje:
a. rozkazy wyjazdu,
b. karty pracy,
c. KUT,
d. Plan Eksploatacji,
e. Plan rotacji akumulatorów i ogumienia oraz opończy,
f. Plan rzeczowo-finansowy,
g. Plan badań diagnostycznych;

- Proszę podać w jakiej formie wykonywane są dokumenty sprawozdawcze, meldunkowe, raporty, zestawienia (np. dla szefów/dowódców):
a. papierowej,
b. w arkuszu kalkulacyjnym MS Excel,
c. w tabelkach MS Word,
d. W ZWSI RON,
e. MS Access,
f. innej (jakiej);

- Czy znane są Pani/Panu następujące pojęcia?
a. IM/WP-68,
b. JIM,
c. $\mathrm{KH}$,
d. IS (jako gestor),
e. ZWSI RON,
f. moduł PM, 
Analysis and testing of reliability information systems in analysis of the... Systemy informatyczne $w$ analizie procesu eksploatacji w wojsku

- Proszę podać, czy w Pani/Pana JW jest stosowany system ZWSI RON

a. tak,

b. nie;

- Proszę podać, czy Pani/Pan wykorzystuje moduł PM do zarządzania eksploatacją?

a. tak,

b. nie;

- Jak ocenia Pani/Pan przyjazność dla użytkownika systemu ZWSI RON?
a. łatwy w obsłudze,
b. zagmatwany,
c. przyjazny,
d. trudny;

- Proszę podać co oznaczają w ZWSI RON następujące terminy:
a. skład,
b. zakład
c. konsygnacja;

- Jakie problemy występują w Pani/Pana JW w procesie ewidencjonowania zdarzeń eksploatacyjnych pojazdów (SpW) (pozostawiono miejsce dla wypowiedzenia się przez respondenta)?

Analizując odpowiedzi na pierwsze pytanie można założyć, że respondenci znają i pracują z typowymi dokumentami eksploatacyjnymi, co przedstawiono graficznie na rysunku 1 .

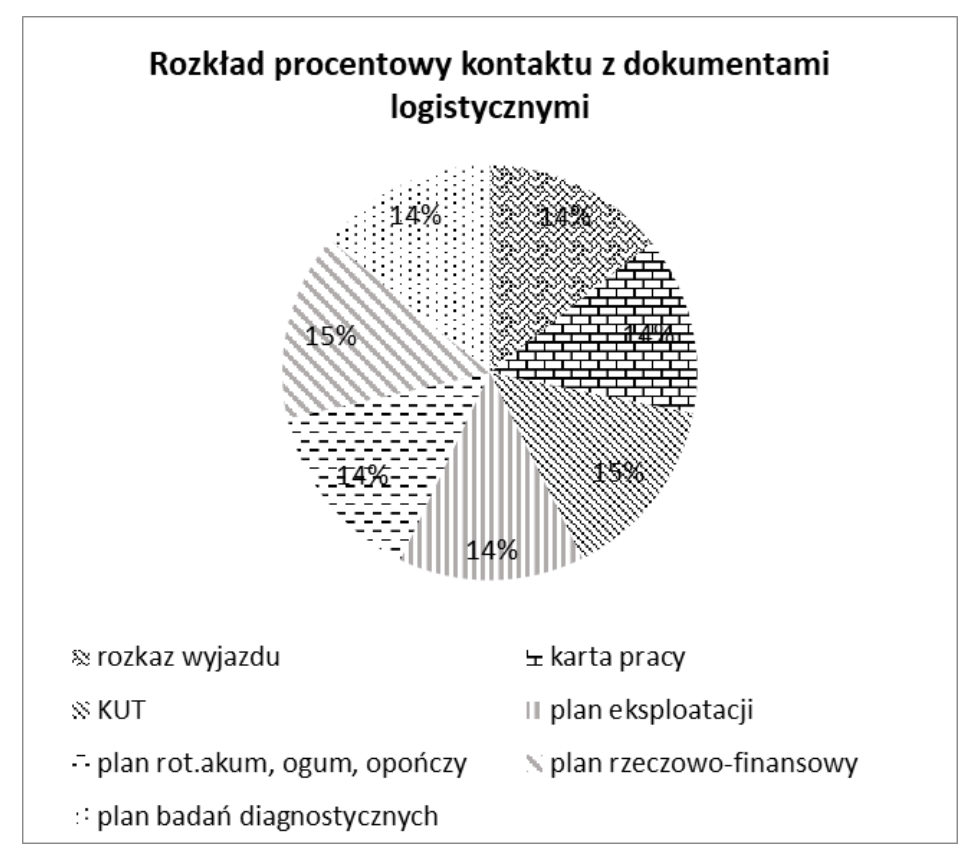

Rys. 1 Rozklad procentowy kontaktu z dokumentami logistycznymi 
Uzyskane odpowiedzi na drugie pytanie wskazują, że 100\% respondentów do sporządzania dokumentów ewidencyjno-sprawozdawczych w procesie eksploatacji SpW wykorzystuje nadal arkusz kalkulacyjny MS Excel, co doskonale obrazuje rysunek 2 .

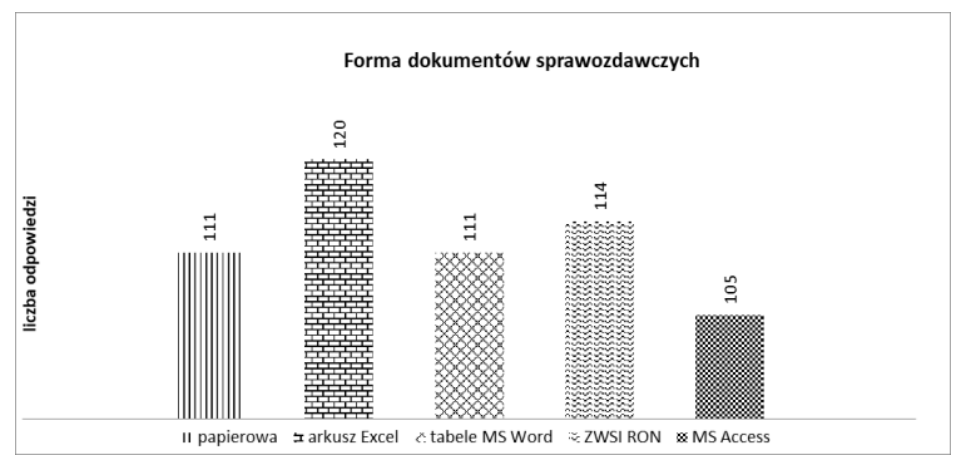

Rys. 2 Forma dokumentów sprawozdawczych

Należy jednak zwrócić uwagę na fakt, że ZWSI RON również w znacznym stopniu jest wykorzystywany do sporządzania przedmiotowych dokumentów (95\% ankietowanych).

Najmniej wykorzystywany jest w powyższym obszarze pakiet MS Access, który jako alternatywne narzędzie dla MS Excel, wymaga od użytkownika większej wiedzy informatycznej.

Odpowiedzi na kolejne - trzecie pytanie, dotyczące znajomości podstawowych pojęć związanych z funkcjonowaniem ZWSI RON świadczą o tym, że podstawowe pojęcia $\mathrm{w}$ tego obszaru są znane większości respondentów na poziomie bardzo dobrym lub dobrym np.: pojęcie JIM umie wyjaśnić 100\% respondentów, a ZWSI RON 96\% respondentów. Znajomość jednak pojęcia moduł PM, jako składowej ZWSI RON na poziomie 50\% wskazuje na to, że nie wszyscy respondenci znają strukturę ZWSI. Większą trudność opiniodawcom sprawiło odpowiadanie na pytanie $\mathrm{nr} 7$, dotyczące bardziej zaawansowanych pojęć związanych z ZWSI RON, co świadczy o przeciętnej (poniżej 50\%) znajomości systemu od strony użytkownika.

Następne, powyżej wyeksponowane pytania $\mathrm{nr} 4$ oraz 5 oraz udzielone na nie odpowiedzi świadczą o tym, że $75 \%$ uczestników badania stosuje ZWSI RON w działalności służbowej, jednak tylko $10 \%$ badanych zadeklarowało wykorzystywanie modułu PM do zarządzania eksploatacją.

Odpowiedzi na pytanie nr 6 dotyczące przyjazności systemu dla użytkownika zostały udzielone poprzez zakreślenie wyróżnionych wskaźników, jak przedstawiono na rysunku 3. 
Analysis and testing of reliability information systems in analysis of the... Systemy informatyczne $w$ analizie procesu eksploatacji w wojsku

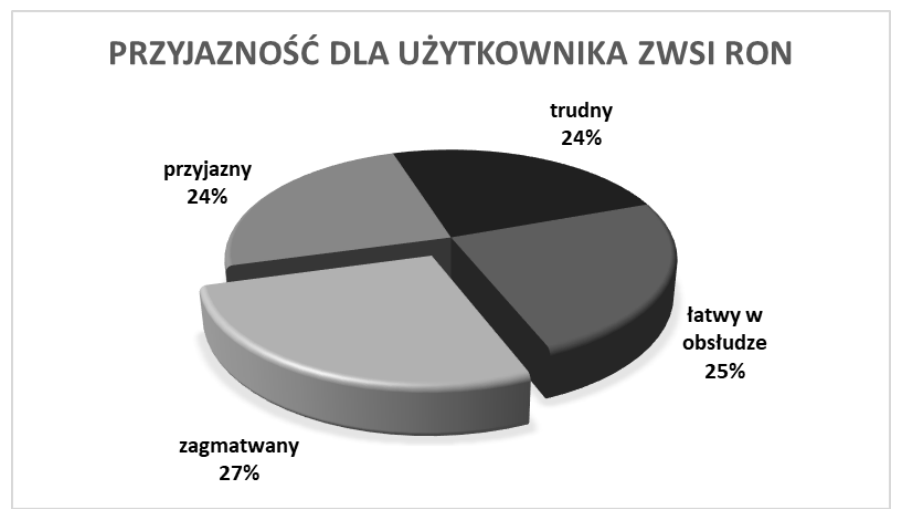

Rys. 3 Przyjazność dla użytkownika

Analizując ocenę systemu ZWSI RON z uwzględnieniem przyjazności dla użytkownika można zauważyć, że rozkład dla poszczególnych wskaźników: przyjazny, trudny, łatwy w obsłudze, zagmatwany, jest zrównoważony. Nie można jednoznacznie stwierdzić na podstawie subiektywnych opinii respondentów czy powyższy system jest łatwy, czy trudny w obsłudze. Jednak największy udział procentowy ( $27 \%$ badanych) stanowią odpowiedzi wskazujące na to, że system jest „zagmatwany”, czyli nieprzyjazny dla użytkownika.

Najwięcej informacji dotyczących wykorzystania systemu ZWSI RON w procesie wsparcia eksploatacji pojazdów wojskowych dostarczyły odpowiedzi respondentów na pytanie nr 8 , które zakładało możliwość wyrażenia swobodnej, pisemnej opinii oraz dokonania oceny przedmiotowego systemu przez opiniującego. Zebrany materiał badawczy w tym zakresie jest dość obszerny, dlatego też poniżej przedstawiono najczęściej występujące odpowiedzi, dotyczące problemów w procesie ewidencjonowania zdarzeń eksploatacyjnych:

- „ZWSI obejmuje tylko ewidencję ilościowa i wartościową, niewdrożony moduł PM”;

- „W ZWSI brak jest prowadzenia planu eksploatacji”;

- „ZWSI dubluje dokumenty lub tworzy niepotrzebne”;

- „ZWSI jest niewydolny, zawiesza sie”;

- „W ZWSI brakuje możliwości generowania meldunków o przyjęciu-przekazaniu pojazdów z innych służb, a inne przepisy tego wymagają";

- „brak wpisów do systemu ZWSI, które są w książkach pojazdu mechanicznego”;

- „braki kadrowe - mały stan osobowy do prowadzenia pełnej dokumentacji eksploatacyjnej";

- „system opóźnia obieg dokumentów”;

- „brak synchronizacji pomiędzy wojskowym oddziałem gospodarczym (WOG) i użytkownikami oraz w relacji WOG-WOG";

- „późne podawanie danych niezbędnych do planowania eksploatacji, nierzetelne dane";

- „brak możliwości odwzorowania zdarzeń eksploatacyjnych w ZWSI RON, ewidencjonowanych w innych służbach logistyki JW, przez służbę czołgowosamochodową". 
Powtarzające się, wyżej przytoczone odpowiedzi respondentów na pytanie $\mathrm{nr} 8$ świadczą o subiektywnych, niezależnych od siebie ocenach i wnioskach dotyczących eksploatacji ZWSI RON. Uczestnicy przedmiotowego badania mogli odpowiadając na powyższe pytanie przekazać swoje spostrzeżenia i wskazać problemy, $\mathrm{z}$ jakimi spotykają się $\mathrm{w}$ czasie codziennej pracy $\mathrm{z}$ powyższym systemem informatycznym. Założenia systemowe ZWSI RON w ich opiniach rozmijają się $\mathrm{z}$ narzuconymi $\mathrm{w}$ instrukcjach branżowych $[1,2]$ czynnościami do wykonania.

\section{Podsumowanie}

Uzyskane wyniki badań świadczą przede wszystkim, że pomimo wdrożenia do eksploatacji ZWSI RON, nadal do sporządzania dokumentów sprawozdawczych, raportów, zestawień itp. używa się $\mathrm{w}$ jednostkach wojskowych rozwiązań alternatywnych. Dane zobrazowane na rysunku 2 doskonale to potwierdzają. Niestety w tym obszarze działalności nadal rozwiązania komercyjne, jak np.: arkusz kalkulacyjny MS Excel, czy MS Access są nieformalnie wdrażane przez osoby funkcyjne pionu logistyki JW, do wspomagania procesów eksploatacji i są wykorzystywane na porównywalnym poziomie, jak w przypadku ZWSI RON [3]. Osoby zajmujące się problematyką informatycznego wsparcia procesów eksploatacji pojazdów na rynku cywilnym, mogą się zastanawiać, dlaczego w jednostkach wojskowych wykorzystuje się dodatkowo (oprócz ZWSI RON) wskazane powyżej narzędzia informatyczne, pomimo powszechnej dostępności bardziej specjalistycznych narzędzi do prowadzenia ewidencji zdarzeń eksploatacyjnych. Wbrew przypuszczeniom nie wynika to tylko z małego zasobu wiedzy informatycznej, czy słabego rozeznania na rynku cywilnym osób funkcyjnych pionów logistyki wojskowej. Należy sobie uświadomić, że komputery użytkowane w JW, włączone do resortowej sieci niejawnej MILNET-Z, posiadają ograniczenia narzucone przepisami ochrony informacji niejawnych. Jednym z tych ograniczeń jest brak możliwości instalacji oprogramowania, które nie jest dopuszczone do użytkowania w sieciach niejawnych przez Służbę Kontrwywiadu Wojskowego. Wspomniane powyżej narzędzia informatyczne MS Excel, czy MS Access, wchodzą w skład pakietu MS Office, który jest instalowany i dostępny w komputerach włączonych do sieci MILNET-Z.

\section{Literatura}

[1] IWsp SZ Służby Techniczne, Instrukcja Zarządzania Eksploatacją Uzbrojenia i Sprzetu Wojskowego w SZ RP Zasady Ogólne, DD/4.22.13, Bydgoszcz, IWsp SZ, 2013.

[2] IWsp SZ Służby Techniczne, Przepisy o gospodarowaniu sprzętem służby czołgowo-samochodowej, DD/4.22.2, Bydgoszcz, IWsp SZ, 2014. 
Analysis and testing of reliability information systems in analysis of the... Systemy informatyczne $w$ analizie procesu eksploatacji w wojsku

[3] Kończak J. Polak K., Radzikowska B., Ewidencjonowanie zdarzeń eksploatacyjnych sprzętu czołgowo-samochodowego w czasie pokoju, spojrzenie w przyszłość, Sulejówek, Belstudio, 2013.

[4] Kuck J., Nowoczesne technologie w logistyce, Wydawnictwo AON, Warszawa 2013.

[5] Markowska K.: Proponowany przebieg współpracy outsourcingowej na przykładzie usług transportu kolejowego ładunków, Organizacja i Zarządzanie, Zeszyty Naukowe Nr 1928, Politechnika Śląska, Gliwice 2015r. s. $249-262$

[6] Samól D., Kuck J., Współczesne metody wsparcia informatycznego dla logistyki kadr i finansów, [w:] Perspektywy informatyzacji logistyki Wojska Polskiego, SG WP, Logis. Wewn. 4/2006.

[7] Simiński P., Wojskowe Pojazdy Kołowe, Bel Studio, Warszawa, 2015

[8] Żółtowski B., Badania zagrożeń utraty zdatności środowiskowych systemów technicznych, Bydgoszcz, Wyd. Ucz. UT-P, 2013.

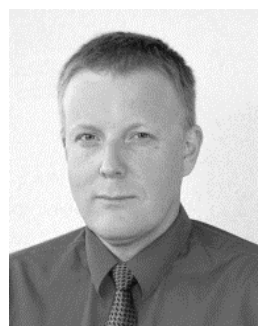

Plk dr hab. inż. Przemyslaw Simiński, absolwent Wydziatu Mechanicznego WAT, zastepca dyrektora WITPiS, profesor nadzwyczajny, menadżer projektu, wyktadowca, dydaktyk (Udziat 40\%).

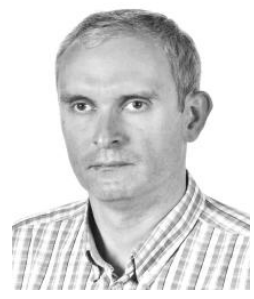

Dr inż. Jarosław Kończak, absolwent Wydziału Mechanicznego WAT, adiunkt WITPiS, logistyk, eksploatator, konstruktor, ergonomista, menadżer projektu (Udziat 30\%).

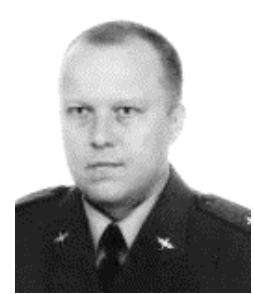

Mjr dr inz. Kamil Przybysz, absolwent Wydziału Mechanicznego WAT, adiunkt Wydziatu Lotniczego WSOSP, logistyk, eksploatator, programista, analityk, menadżer systemów informatycznych (Udziat 30\%). 